\title{
The Development of Rubber, Coffee and Palm Oil Commodity in South Sumatra, Indonesia using Swot Analysis
}

\author{
Syamsurijal A. Kadir ${ }^{1}$, Rulyanti Susi Wardhani ${ }^{2}$, Nurkadina Novalia ${ }^{3}$, Ahmad \\ Maulana ${ }^{4}$
}

\author{
${ }^{1}$ Faculty of Economics, University of Sriwijaya, Indonesia, \\ ${ }^{2}$ Fakultas of Economics, University of Bangka Belitung, Indonesia, \\ ${ }^{3}$ Fakultas of Economics, University of IBA, Indonesia, \\ ${ }^{4}$ Fakultas of Economics, University of Sriwijaya, Indonesia
}

\begin{abstract}
The purpose of this research is to re-analyze the internal and external factors that become the strength, the weakness, the opportunities and the threat in implementing the strategy of Rubber, Coffee and Palm Oil commodity development in South Sumatera Province. Analysis tool used with SWOT approach. The results show that the districts/cities in the province of South Sumatra superior commodities rubber, coffee, and oil palm are in the area of aggressive strategy. Factors that become the main force for the land area with high soil fertility.
\end{abstract}

Keywords-Leading Commodity, Rubber, Coffee, Oil Palm and SWOT Analysis.

JEL Classifications:A10,B49,H19

\section{INTRODUCTION}

The agricultural sector, in particular, the plantation sub-sector has a role to improve the economy in a country or region. So the plantation sub-sector is one of the natural wealth owned by the Indonesian nation. The plantation business has an important and strategic role in national development, especially in increasing the prosperity and prosperity of the people, the state income of foreign exchange, the provision of employment, the acquisition of added value and competitiveness, the fulfillment of domestic consumption needs, even the raw materials of domestic industry (Hadiguna, 2012; Hafif, Ernawati, \& Pujiarti, 2014).

According to the Law of the Republic of Indonesia Number 39 the Year 2014 that plantations are all activities of natural resources management, human resources, production facilities, tools and machinery, cultivation, harvesting, processing, and marketing related plantation crops. Plantation crops are a major supporter of the agricultural sector in generating foreign exchange resulting in the export of Indonesia's main agricultural commodities from plantations. Plantation products that are exported include palm oil, rubber, tea, coffee and tobacco (Dumairy, 1997).

The contribution of the agricultural sectorcannot be doubted for the country's foreign exchange. According to Central Bureau of Statistics Central Jakarta (2017), the agricultural sector is the second most influential sector to growth, after processing industry, and still above the trade and construction sector. For the second quarter of 2017, the agricultural sector contributed 13.92 percent while in the quarter I 2017 contributed 13.59 percent increased by 0.33 percent. Although there is an increase in plantation sub-sector to economic growth, there are some problems faced, namely the area of plantation sub-sector is slowing down, productivity level tends to slow down, lack of infrastructure in plantation center (Ministry of Agriculture Directorate General of Plantation, 2016).

Establishment of plantations in South Sumatera Province can be reflected in the last three years with the area of smallholder plantations continue to increase with a total area of 2012 in the area of 2,429,132 Ha, 2013 to 2,542,801 Ha, and in 2014 of 2,620,992 Ha, most of the commodities cultivated by rubber, palm oil, coffee, coconut and other commodities of hope. Although plantation production has increased in the last three years with details of total plantation production in 2012 amounted to 3,562,990 Ton, in 2013 of 3,845,982 Ton, and in 2014 amounted to 4,114,840 Ton.

According to BPS of South Sumatera Province, the largest rubber producer in Indonesia is South Sumatera Province followed by North Sumatra and Riau. Of the total rubber production in Indonesia, 20\% of production is produced by South Sumatera Province (Plantation Office of South Sumatra Province, 2016).

The existence of agriculture sub-sector problem above is needed the strategy so that superior product development 
in South Sumatera Province can compete in the international arena so that will increase exports which is superior from that province with an approach of Strengths, Weaknesses, Opportunities, and Threats. This analysis is based on the ability to find and the environment, so that the strategy can actually be realized from the strength it has and the opportunities it faces. The activities in the SWOT analysis process are to unders tand all information in a case, analyze the situation to find out what issues are going on and decide what action should be taken to solve the problem (Collett, 1999; Rangkuti, 2006; Valeriani \& Wardhani, 2015; Wardhani \& Valeriani, 2016).

This research refers to Nuga \& Asimiea (2015) research in Negeria, Akhtar \& Pirzada (2014) in Pakistan, Panca \& Anhar (2013) and Wahyudy \& Asrol (2015), so it is necessary to re-analyze internal and external factors of strength, opportunities, and threats in implementing the strategy of developing Rubber, Coffee and Palm Oil commodities in South Sumatera Province.

\section{LITERATURE REVIEW}

Commodities are the main commodities, commercial goods, crops and local handicrafts can be used as export commodities or raw materials which can be classified according to their quality in accordance with international trade standards (F.Rahardi, 2004; Marx, 1895). These commodities or commodities are said to be superior commodities according to Ely (2014) and Lahiani, Nguyen, \& Vo, (2013) are potential commodities that are seen as winning a competition with similar products in other regions. Such advantages can be attained due to their high production efficiency due to the high bargaining position of both suppliers, buyers, and high competitiveness to competitors, new entrants, and substitutes.

According to the Directorate General for Regional Development of the Ministry of Home Affairs (1999) the following criteria of commodities are as follows: 1) having prominent and innovative local content in agriculture, industry and services, 2) having high competitiveness in the market, both in terms of quality, (3) Having the characteristic of the region because of the involvement of the local community (local labor), 4) having the guarantee and the raw material content which is sufficiently, stable, and sustainable, 5) Focused on high value-added products, both in packaging and processing, 6) Economically beneficial and beneficial to increase the income and capabilities of human resources and 7) Environmentally friendly, non-destructive to the environment, sustainable and non-destructive to local culture.
International trade is an act of exchange of goods and services made by a resident of a country with a resident of another country on the basis of mutual agreement. International trade is driven by the diversity of resources between countries (Nopirin, 1999). The main factor that is the reason for the country to trade internationally is the difference of resources between countries and each country aimed at achieving economies of scale in production (Krugman, Obstfeld, \& Melitz, 2012). Differences between countries that encourage international trade are differences in natural resources, capital resources, labor and technology resulting in differentiation of production efficiency between countries (Halwani, 2002). Foreign trade has a very important role in economic growth and economic development of a country. The growth model developed by Keynes, international trade is one of the variables that affect a country income.

SWOT stands for strengths, weaknesses, opportunities, and threats. Understandings of strengths, weaknesses, opportunities, and threats in the SWOT analysis (Rangkuti, 2006). According to Jurevicius (2013) and Harris on (2010) the SWOT analysis component is: 1) Strenght $(\mathrm{S})$ is strength analysis, situation or condition that is the strength of an organization or company at the moment, 2) Weaknesses (W) is weakness analysis, situations or conditions that are the weakness of an organization or company at this time, 3) Opportunity (O) is the analysis of opportunities, situations or conditions that are opportunities outside an organization or company and provide opportunities for the organization to grow in the future, 4) Threats ( $\mathrm{T}$ ) is threat analysis, how to analyze the challenges or threats that must be faced by a company or organization to deal with a variety of unfavorable environmental factors on a company or organization that causes decline. If not immediately overcome, the threat will be a barrier for a business concerned either in the present or in the future.

\section{METHODOLOGY}

In order to obtain internal and external factors in developing rubber, coffee and palm oil commodities in South Sumatera Province, descriptive research method is used. The identification of internal and external factors is done by using Internal analysis tool - External Strategic Factor Analysis Summary (IFAS - EFAS), Space Matrix and SWOT Matrix.

The analytical stages in the SWOT are utilizing all data and information in the quantitative models of strategy formulation (Rangkuti, 2006; Coman \& Ronen, 2009). SWOT analysis is first done by scanning. The use of some analysis will be better so as to produce a strategy formula that can solve the problems and strategies that are 
formed in accordance with the objectives and the environment it faces.

\section{DATA AND RESULT}

4.1 Analysis of Internal and External Environment In analyzing the SWOT and strategy of superior product policy, the researcher analyzes each commodity by taking into account internal factors and external factors for internal factors are land availability, commodity quality, skill quality, labor quantity, production scale, product derivation while external factor price, the market, the number of traders, technology, institutions, and infrastructure. Based on the results of surveys, observations, interviews and FGDs, internal environmental analyzes consisting of strengths, weaknesses (Weakness) and external environmental analyzes consisting of opportunities (Opportunities) and threats from the development of superior rubber, coffee, and palm oil products can be seen in Table 1 .

Tabel.1: Matriks Internal factory rubber, Coffee, Palm Oil Commodity

\begin{tabular}{|c|c|c|c|}
\hline \multicolumn{4}{|c|}{ 1. Rubber Commodity } \\
\hline \multicolumn{2}{|r|}{ STRENGTHS } & \multicolumn{2}{|r|}{ WEAKNESS } \\
\hline 1 & $\begin{array}{l}\text { Has a large area of land, soil fertility is high } \\
\text { and productive }\end{array}$ & 1 & Product quality is still low \\
\hline 2 & Number of manpower available & 2 & $\begin{array}{l}\text { Product derivatives are still a lot of work in other } \\
\text { regencies or provinces. }\end{array}$ \\
\hline 3 & $\begin{array}{l}\text { Medium-scale production scale to large } \\
\text { scale }\end{array}$ & 3 & Some work skills are still low \\
\hline \multicolumn{4}{|c|}{ EXTERNAL FACTOR } \\
\hline \multicolumn{2}{|r|}{ OPPORTUNITIES } & \multicolumn{2}{|r|}{ THREATS } \\
\hline 1 & $\begin{array}{l}\text { The number of suppliers that supply } \\
\text { relatively many }\end{array}$ & 1 & Rubber prices fluctuate \\
\hline 2 & $\begin{array}{l}\text { Only some districts/cities are using } \\
\text { appropriate technology }\end{array}$ & 2 & Institutions are not yet supportive \\
\hline 3 & $\begin{array}{l}\text { Both local and domestic markets are } \\
\text { available even in overseas exports }\end{array}$ & 3 & Infrastructure is not adequate \\
\hline \multicolumn{4}{|c|}{ 2. Coffee Commodity } \\
\hline \multicolumn{4}{|c|}{ INTERNAL FACTOR } \\
\hline \multicolumn{2}{|r|}{ STRENGTHS } & \multicolumn{2}{|r|}{ WEAKNESS } \\
\hline 1 & $\begin{array}{l}\text { Has a large area of land, fertility is high } \\
\text { and productive }\end{array}$ & 1 & Some work skills are still low \\
\hline 2 & $\begin{array}{l}\text { Derivative products of new instant coffee } \\
\text { and powder, but will be developed other } \\
\text { products, because of the more coffee with } \\
\text { a variety of flavors. }\end{array}$ & 2 & Scale production in small-scale districts/cities \\
\hline 3 & Number of manpower available & 3 & Some quality or quality of coffee is low \\
\hline \multicolumn{4}{|c|}{ EXTERNAL FACTOR } \\
\hline \multicolumn{2}{|r|}{ OPPORTUNITIES } & \multicolumn{2}{|r|}{ THREATS } \\
\hline 1 & $\begin{array}{l}\text { Coffee market opportunities in Indonesia } \\
\text { in the future is quite bright }\end{array}$ & 1 & $\begin{array}{l}\text { Coffee prices fluctuate and compete with other } \\
\text { countries }\end{array}$ \\
\hline 2 & Institutional support & 2 & Technology is still traditional \\
\hline 3 & $\begin{array}{l}\text { The number of suppliers that supply } \\
\text { relatively many }\end{array}$ & 3 & Infrastructure is not adequate \\
\hline \multicolumn{4}{|c|}{ 3. $\quad$ Palm Oil } \\
\hline \multicolumn{4}{|c|}{ INTERNAL FACTOR } \\
\hline \multicolumn{2}{|r|}{ STRENGTHS } & \multicolumn{2}{|r|}{ WEAKNESS } \\
\hline 1 & $\begin{array}{l}\text { Has a large area of land, fertility is high } \\
\text { and productive }\end{array}$ & 1 & The product derivatives are still small \\
\hline
\end{tabular}




\begin{tabular}{|c|c|c|c|}
\hline 2 & $\begin{array}{l}\text { Scale production in districts/cities of } \\
\text { medium and large scale }\end{array}$ & 2 & Product quality is still low \\
\hline 3 & Number of manpower available & 3 & The number of merchants supplied is still small \\
\hline \multicolumn{4}{|c|}{ EXTERNAL FACTOR } \\
\hline \multicolumn{2}{|r|}{ OPPORTUNITIES } & \multicolumn{2}{|r|}{ THREATS } \\
\hline 1 & $\begin{array}{l}\text { Both local and domestic markets are } \\
\text { available even in overseas exports. }\end{array}$ & 1 & $\begin{array}{l}\text { Palm oil prices fluctuate and compete with other } \\
\text { countries }\end{array}$ \\
\hline 2 & Institutional support & 2 & Product derivatives are still low \\
\hline 3 & Technology can be done with appropriate & 3 & Infrastructure is not adequate \\
\hline
\end{tabular}

4.2 Analysis of IFAS Strategic Factors - EFAS

After analyzing the internal and external conditions of the leading commodities of rubber, the calculation of internal and external factors is weighted to determine the location of the strategic development quadrant that is considered urgent to do. The calculation of factor weight is done by tabulating the score of EAS - EFAS. The following is a calculation of the internal and external factor weights contained in the IFAS and EFAS analysis tables shown in the following table 2

Tabel.2: Calculation of Internal and External Factor Scoring Score of Rubber Commodity

\begin{tabular}{|c|c|c|c|c|}
\hline \multirow[t]{2}{*}{ No } & Factor-Factor & Weight & Rating & Value \\
\hline & \multicolumn{4}{|l|}{ Internal Factor } \\
\hline & Strenght & & & \\
\hline 1 & $\begin{array}{l}\text { Has a large area of land, soil fertility is high and } \\
\text { productive }\end{array}$ & 0,34 & 4 & 1,36 \\
\hline 2 & Number of manpower available & 0,33 & 3 & 0,99 \\
\hline \multirow[t]{3}{*}{3} & Medium-scale production scale to large scale & 0,33 & 2 & 0,66 \\
\hline & Amount & $\mathbf{1 , 0 0}$ & & 3,01 \\
\hline & Weakness & & & \\
\hline 1 & Productivity quality is still low & 0,33 & 2 & 0,66 \\
\hline 2 & Institutions are not yet supportive & 0,34 & 2 & 0,68 \\
\hline \multirow[t]{3}{*}{3} & Some work skills are still low & 0,33 & 1 & 0,33 \\
\hline & Amount & $\mathbf{1 , 0 0}$ & & 1,67 \\
\hline & Opportunities & & & \\
\hline 1 & The number of suppliers that supply relatively many & 0,35 & 4 & 1,4 \\
\hline 2 & $\begin{array}{l}\text { Only some districts/cities are using appropriate } \\
\text { technology }\end{array}$ & 0,30 & 3 & 0,6 \\
\hline \multirow[t]{3}{*}{3} & $\begin{array}{l}\text { Both local and domestic markets are available even in } \\
\text { overseas exports }\end{array}$ & 0,35 & 2 & 0,7 \\
\hline & Amount & $\mathbf{1 , 0 0}$ & & 2,7 \\
\hline & Threats & & & \\
\hline 1 & Rubber prices fluctuate & 0,4 & 2 & 0,8 \\
\hline 2 & Institutions are not yet supportive & 0,2 & 2 & 0,4 \\
\hline \multirow[t]{4}{*}{3} & Infrastructure is not adequate & 0,4 & 3 & 1,2 \\
\hline & Amount & $\mathbf{1 , 0 0}$ & & 2,4 \\
\hline & $\mathrm{S}-\mathrm{W}=3,01-1,67=1,34$ & & & \\
\hline & $\mathrm{O}-\mathrm{T}=2,7-2,4=0,3$ & & & \\
\hline
\end{tabular}

Table.3: Calculation of Internal and External Factor Scoring Score of Coffee Commodity

\begin{tabular}{|l|l|c|c|c|}
\hline \multirow{2}{*}{ No } & \multicolumn{1}{|c|}{ Factor-Factor } & Weight & Rating & Value \\
\cline { 2 - 5 } & \multicolumn{1}{|c|}{ Internal Factor } & & & \\
\hline & Strenght & & & \\
\hline 1 & Has a large area of land, soil fertility is high and & 0,3 & 3 & 0,9 \\
\hline
\end{tabular}




\begin{tabular}{|c|c|c|c|c|}
\hline & productive & & & \\
\hline 2 & $\begin{array}{l}\text { Derivative products of new instant coffee and powder, } \\
\text { but will be developed other products, because of the } \\
\text { more coffee with a variety of flavors. }\end{array}$ & 0,5 & 3 & 1,5 \\
\hline \multirow[t]{3}{*}{3} & Number of manpower available & 0,2 & 2 & 0,6 \\
\hline & Amount & $\mathbf{1 , 0 0}$ & & $\mathbf{3 , 0 0}$ \\
\hline & Weakness & & & \\
\hline 1 & Some work skills are still low & 0,3 & 2 & 0,6 \\
\hline 2 & Scale production in small-scale districts/cities & 0,3 & 3 & 0,9 \\
\hline \multirow[t]{3}{*}{3} & Some quality or quality of coffee is low & 0,4 & 3 & 1,2 \\
\hline & Amount & $\mathbf{1 , 0 0}$ & & 2,67 \\
\hline & Opportunities & & & \\
\hline 1 & $\begin{array}{l}\text { Coffee market opportunities in Indonesia in the future is } \\
\text { quite bright }\end{array}$ & 0,4 & 3 & 1,2 \\
\hline 2 & Institutional support & 0,3 & 3 & 0,9 \\
\hline \multirow[t]{3}{*}{3} & The number of suppliers that supply relatively many & 0,3 & 3 & 0,9 \\
\hline & Amount & $\mathbf{1 , 0 0}$ & & $\mathbf{3 , 0 0}$ \\
\hline & Threats & & & \\
\hline 1 & Coffee prices fluctuate and compete with other countries & 0,4 & 3 & 1,2 \\
\hline 2 & Technology is still traditional & 0,3 & 1 & 0,3 \\
\hline \multirow[t]{4}{*}{3} & Infrastructure is not adequate & 0,3 & 3 & 0,9 \\
\hline & Amount & $\mathbf{1 , 0 0}$ & & 2,4 \\
\hline & $\mathrm{S}-\mathrm{W}=3-2,67=0,33$ & & & \\
\hline & $\mathrm{O}-\mathrm{T}=3-2,4=0,56$ & & & \\
\hline
\end{tabular}

Table.4: Calculation of Internal and External Factor Score Oil Palm Commodity

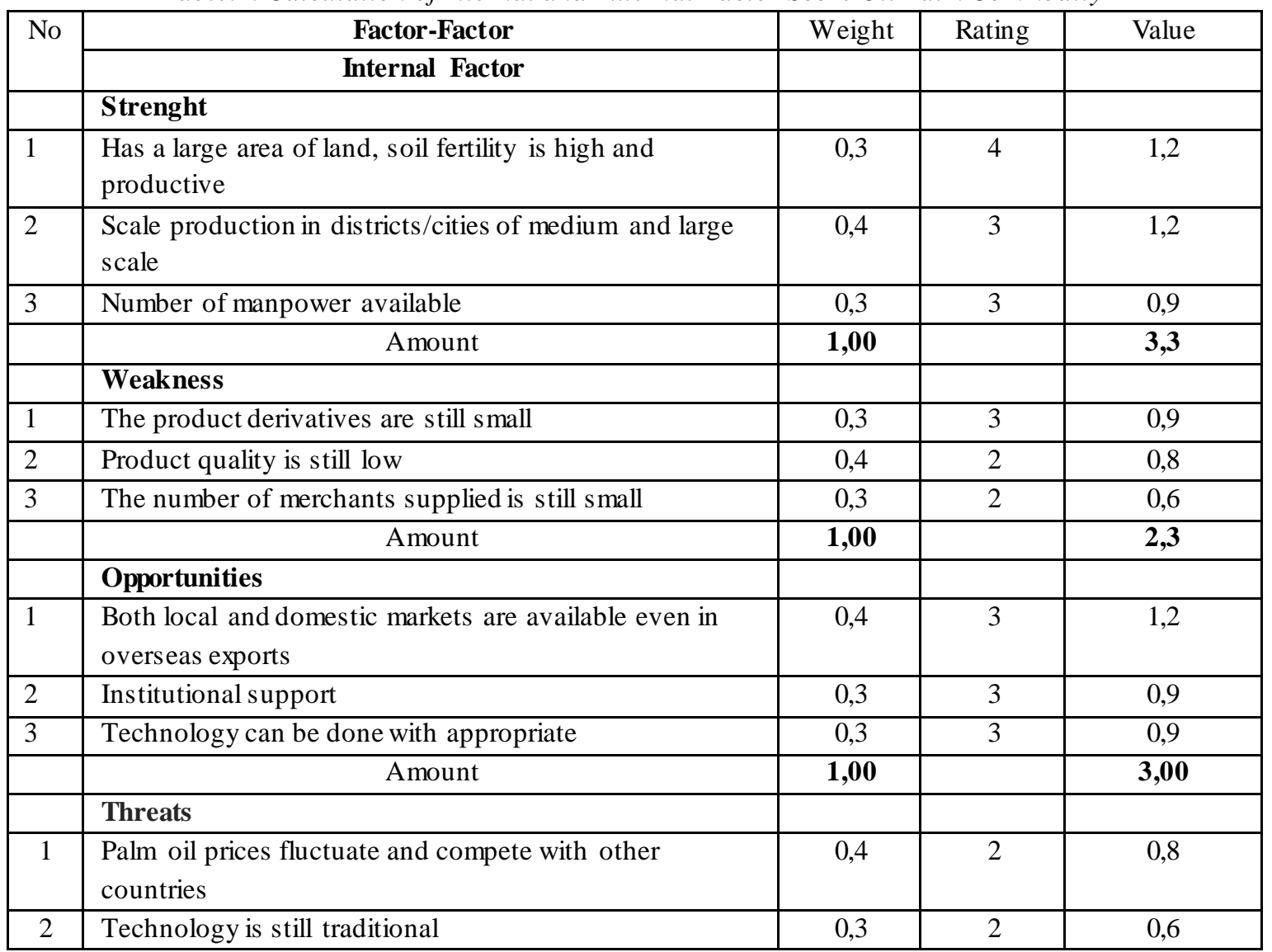




\begin{tabular}{|c|l|c|c|c|}
\hline 3 & Infrastructure is not adequate & 0,3 & 2 & 0,6 \\
\hline & Amount & $\mathbf{1 , 0 0}$ & & $\mathbf{2 , 0 0}$ \\
\hline & $\mathrm{S}-\mathrm{W}=3,3-2,3=1,0$ & & & \\
\hline & $\mathrm{O}-\mathrm{T}=3,0-2,0=1,0$ & & & \\
\hline
\end{tabular}

Based on the above table and the strengths, weaknesses, opportunities, and threats of the three leading commodities that can be seen in Figures 1, 2 and 3

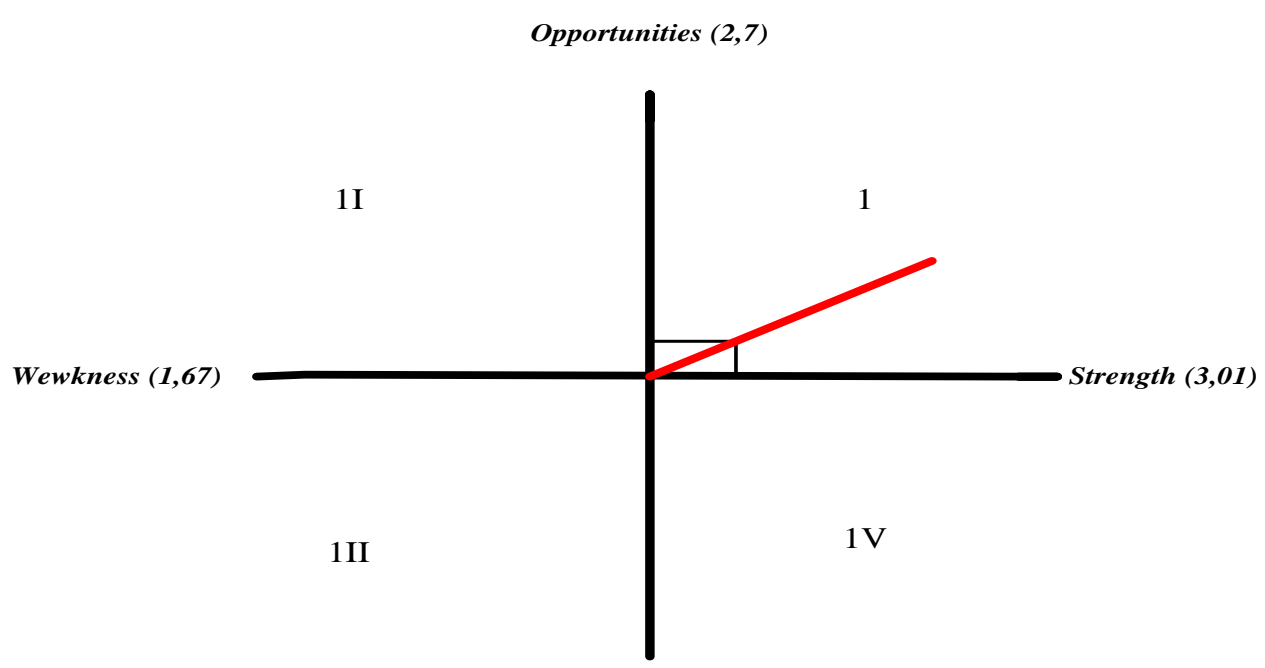

Threats $(2,4)$

Picture: 1 Diagram of SWOT Analysis Rubber Commodity

Opportunities (3,00)

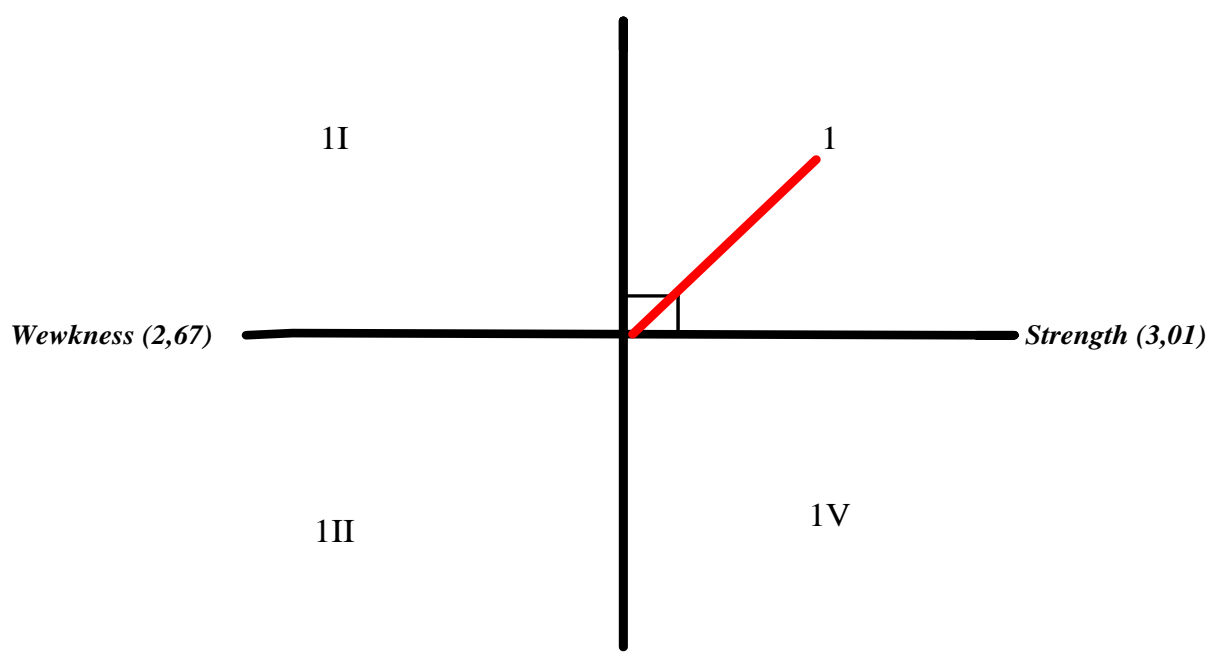

Threats $(2,4)$

Gambar: 2 Diagram Of SWOT Analysis Coffee Commodity 


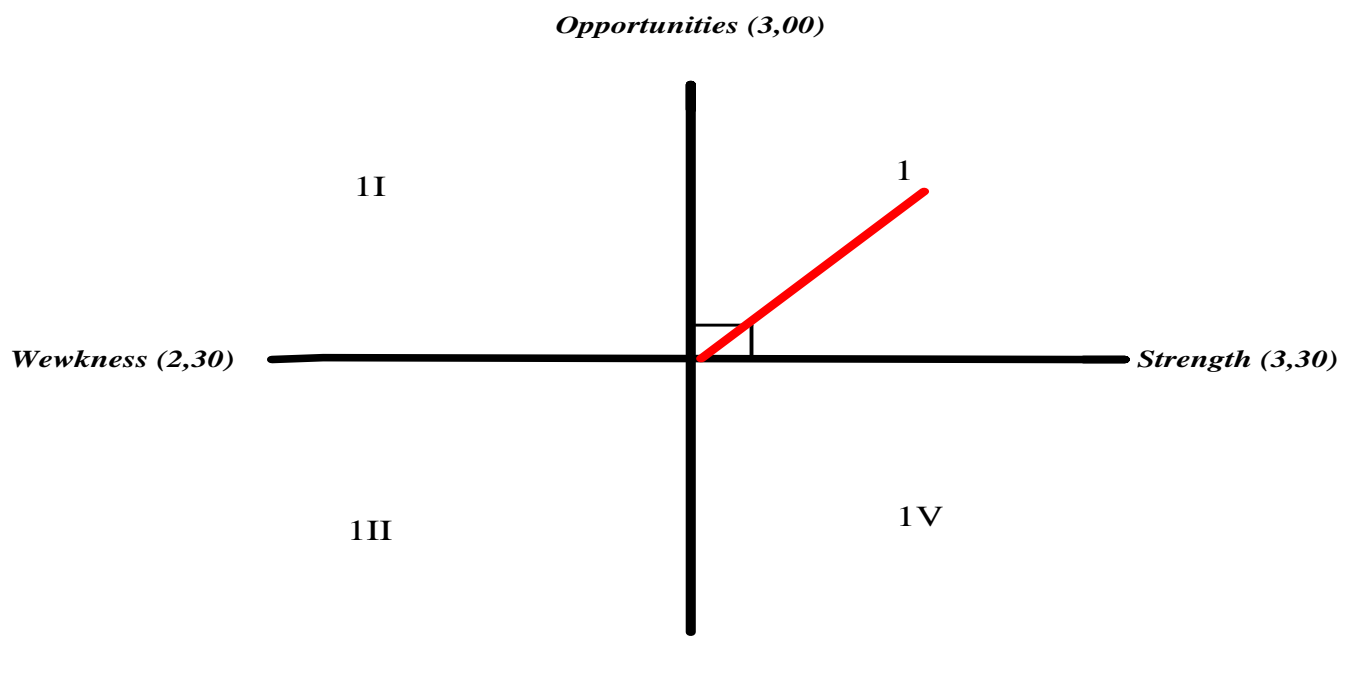

Threats (2,0)

Gambar: 3 Diagram Of SWOT Analysis Palm Oil Commodity

Based on the quadrant's location formulation in the Drawing Strategy that is urgent to be implemented in the framework of developing rubber, coffee and palm oil commodities in South Sumatera province in quadrant I (due to its value + ) or lies between external opportunities and internal strength and includes into areas of aggressive strategy for that formulation aggressive strategy to develop rubber, coffee and palm oil commodity Table:

\section{Table.5: Aggressive Strategy Formulation of Rubber Commodity Development}

\begin{tabular}{|c|c|c|}
\hline External Factor & $\begin{array}{l}\text { Strength } \\
\text { - Has a large area of land, } \\
\text { fertility is high and } \\
\text { productive } \\
\text { The number of manpower } \\
\text { available. } \\
\text { Medium to large scale } \\
\text { production scale }\end{array}$ & $\begin{array}{l}\text { Weakness } \\
\text { - Product quality is still low } \\
\text { - Product derivatives are still } \\
\text { a lot of work in other } \\
\text { regencies or provinces } \\
\text { - Some work skills are still } \\
\text { low }\end{array}$ \\
\hline $\begin{array}{l}\text { Opportunity } \\
\text { - The number of suppliers that } \\
\text { supply relatively many } \\
\text { - Only some districts/cities are } \\
\text { using appropriate technology. } \\
\text { Local and domestic markets } \\
\text { are available even in overseas } \\
\text { exports }\end{array}$ & $\begin{array}{l}\text { Strategy S-O } \\
\text { - Optimizing the available land } \\
\text { by replanting the crops in } \\
\text { collaboration with the traders } \\
\text { who supply the ingredients in } \\
\text { the process of the cremation } \\
\text { so that it has added value. } \\
\text { - Optimizing Workforce } \\
\text { available in the use of } \\
\text { technology. } \\
\text { - Increase larger production } \\
\text { scale with better-standardized } \\
\text { rubber export. }\end{array}$ & $\begin{array}{l}\text { Strategy W-O } \\
\text { - Improve quality and } \\
\text { synergize with merchants } \\
\text { - Increase product derivatives } \\
\text { with good technology based } \\
\text { so that the product is in } \\
\text { accordance with national and } \\
\text { international standards. } \\
\text { Increase labor skills for the } \\
\text { rubber market to penetrate } \\
\text { foreign markets }\end{array}$ \\
\hline $\begin{array}{l}\text { Threat } \\
\text { - } \quad \text { Rubber prices fluctuate } \\
\text { - Institutions are not yet } \\
\text { supportive } \\
\text { - Infrastructure is not adequate }\end{array}$ & $\begin{array}{l}\text { Strategy S-T } \\
\text { Make rules or policies } \\
\text { related to land used and } \\
\text { inflatable prices remain } \\
\text { stable or tend to increase } \\
\text { despite world market }\end{array}$ & $\begin{array}{l}\text { Strategy W-T } \\
\text { - The quality of the product is } \\
\text { improved so that the price can } \\
\text { go hand in hand with the } \\
\text { others } \\
\text { - Product derivatives are re- }\end{array}$ \\
\hline
\end{tabular}




\begin{tabular}{|c|c|c|}
\hline & $\begin{array}{l}\text { conditions decline. } \\
\text { Strengthening of regional } \\
\text { commodity institutions and } \\
\text { their marketing and } \\
\text { networking } \\
\text { - Increased infrastructure such } \\
\text { as roads to remote areas in } \\
\text { the area, the plantation is } \\
\text { still red so if it rains, it is } \\
\text { difficult to enter the area. }\end{array}$ & $\begin{array}{l}\text { created with distinctive } \\
\text { features that exist in the } \\
\text { region and synergize with } \\
\text { related copper like banks, } \\
\text { cooperatives, and others. } \\
\text { - Improving the quality of the } \\
\text { workforce is not only related } \\
\text { to the productivity of rubber } \\
\text { commodities but in the future, } \\
\text { the product of marketing and } \\
\text { marketing. }\end{array}$ \\
\hline
\end{tabular}

Table.6: Aggressive Strategy Formulation of Coffee Commodity Development

\begin{tabular}{|c|c|c|}
\hline FaktorEksternal & $\begin{array}{l}\text { Strength } \\
\text { - Has a large area of land, } \\
\text { fertility is high and productive } \\
\text { - Derivative products of new } \\
\text { instant coffee and powder, but } \\
\text { will be developed other } \\
\text { products, because of the more } \\
\text { coffee with a variety of flavors } \\
\text { - Number of manpower } \\
\text { available }\end{array}$ & $\begin{array}{l}\text { Weakness } \\
\text { - } \quad \text { Some work skills are still low } \\
\text { - Scale production in small- } \\
\text { scale districts/cities } \\
\text { - Some quality or quality of } \\
\text { low coffee }\end{array}$ \\
\hline $\begin{array}{l}\text { Opportunity } \\
\text { - Coffee market opportunities } \\
\text { in Indonesia in the future is } \\
\text { quite bright } \\
\text { - Institutional Support } \\
\text { - The number of suppliers that } \\
\text { supply relatively many }\end{array}$ & $\begin{array}{l}\text { Strategy S-U } \\
\text { - Optimizing available land by } \\
\text { replanting crops so that } \\
\text { market opportunities increase } \\
\text { - Institutional strengthening of } \\
\text { farmers to create a derivative } \\
\text { of coffee products with } \\
\text { several different flavors. } \\
\text { - Optimizing the number of } \\
\text { available manpower as well as } \\
\text { establishing cooperation with } \\
\text { merchants who supply tools of } \\
\text { production equipment etc. }\end{array}$ & $\begin{array}{l}\text { Strategy W-O } \\
\text { - Increase labor skills for the } \\
\text { coffee market to penetrate } \\
\text { foreign markets to increase. } \\
\text { - Increase the scale of } \\
\text { production by doing } \\
\text { institutional development } \\
\text { - Improve the quality of coffee } \\
\text { beans with traders supplying } \\
\text { related to the quality of } \\
\text { quality seeds. }\end{array}$ \\
\hline $\begin{array}{l}\text { Threat } \\
\text { - Coffee prices fluctuate and } \\
\text { compete with other countries } \\
\text { - Technology is still traditional } \\
\text { - Infrastructure is adequate }\end{array}$ & $\begin{array}{l}\text { - Strategi S-T } \\
\text { Make rules or policies } \\
\text { related to land used and } \\
\text { coffee prices are not } \\
\text { fluctuating remain stable or } \\
\text { tend to increase despite } \\
\text { world market conditions } \\
\text { decline. } \\
\text { An innovation of processed } \\
\text { products with good } \\
\text { technology } \\
\text { Increased infrastructure }\end{array}$ & $\begin{array}{l}\text { Strategi W-T } \\
\text { - Increase the skill of labor in } \\
\text { processed so that price can } \\
\text { bargaining with others. } \\
\text { - The scale of production is } \\
\text { further enhanced through } \\
\text { good technology } \\
\text { - Increased quality of coffee } \\
\text { with supporting facilities and } \\
\text { infrastructure. }\end{array}$ \\
\hline
\end{tabular}


Table.7: Aggressive Strategy Formulation of Palm Oil Commodity Development

\begin{tabular}{|c|c|c|}
\hline FaktorEksternal & $\begin{array}{l}\text { Strength } \\
\text { - Has a large area of land, } \\
\text { fertility is high and } \\
\text { productive. } \\
\text { - Medium and large production } \\
\text { scale } \\
\text { - Number of manpower, widely } \\
\text { available }\end{array}$ & $\begin{array}{l}\text { Weakness } \\
\text { - The product derivatives are } \\
\text { still small } \\
\text { - } \quad \text { Product quality is still low } \\
\text { - The number of merchants } \\
\text { supplied is still small }\end{array}$ \\
\hline $\begin{array}{l}\text { Opportunity } \\
\text { - } \quad \text { Both local and domestic } \\
\text { markets are available even } \\
\text { in overseas exports } \\
\text { - } \text { Institutional support } \\
\text { - Technology can be done } \\
\text { with appropriate }\end{array}$ & $\begin{array}{l}\text { Strategi S-O } \\
\text { - Optimizing available land by } \\
\text { replanting crops so that } \\
\text { market opportunities increase. } \\
\text { - Increase the scale of } \\
\text { production with greater } \\
\text { institutional strengthening } \\
\text { - The amount of manpower } \\
\text { available is much more } \\
\text { optimized and can use the } \\
\text { right technology }\end{array}$ & $\begin{array}{l}\text { - Strategi W-O } \\
\text { - } \text { Increase product derivatives } \\
\text { so that exports are no longer } \\
\text { raw materials } \\
\text { - } \quad \text { Improve product quality } \\
\text { with institutional } \\
\text { strengthening } \\
\text { - Use of appropriate } \\
\text { technology in synergy with } \\
\text { merchants suppliers }\end{array}$ \\
\hline $\begin{array}{l}\text { Threat } \\
\text { - } \quad \text { Prices fluctuate } \\
\text { - } \text { Institutions are not yet } \\
\text { supportive } \\
\text { - Infrastructure is not } \\
\text { adequate }\end{array}$ & $\begin{array}{l}\text { Strategi S-T } \\
\text { - Creating rules or policies } \\
\text { related to land used and } \\
\text { fluctuating coffee prices } \\
\text { remain stable or tend to } \\
\text { increase despite world } \\
\text { market conditions decline. } \\
\text { - Strengthening of regional } \\
\text { commodity institutions and } \\
\text { their marketing and } \\
\text { networking } \\
\text { Increased infrastructure such } \\
\text { as roads to remote areas in } \\
\text { the area, because the } \\
\text { plantation is still red so if it } \\
\text { rains, it is difficult to enter } \\
\text { the area. }\end{array}$ & $\begin{array}{l}\text { Strategi W-T } \\
\text { - The product derives not only } \\
\text { CPO or cooking oil but more } \\
\text { innovative creates a product } \\
\text { derivative at an affordable } \\
\text { price society. } \\
\text { - Product quality is enhanced } \\
\text { by institutional strengthening. } \\
\text { - Increased infrastructure }\end{array}$ \\
\hline
\end{tabular}

The South Sumatra government should coordinate with regencies and municipalities in relation to the area of rubber commodities despite replanting (rejuvenation) of rubber commodities with a rejuvenation area in 2017 of 14,750 ha, the expansion of this rejuvenation is lower than in 2016 of 19,600 (Ha). The rejuvenation fund is funded by the government such as seed provision, fertilizer, and pois on grass. For the supply must be in coordination with the merchant supplying because government funds fall somewhat slowly so that suppliers can supply suppliers with the payment can be done if the fund has been liquid or in other words the debt first. Then the government issued funds on land rejuvenation must also take into account its workforce, from funds launched by the government of 5.6 million used for seeds, fertilizers, and poison grass. The number of available manpower must improve the quality or skill of continuing education in the hope of increasing rubber productivity and can compete with other countries .

Rubber market is not only the raw materials that are exported but the derivative products that have characteristic of South Sumatera province considering South Sumatra are often done an international event. Increasing the scale was small to large scale with support from the government and the community as well as capital support and cooperation with investors both from within and abroad. For large-scale companies still, maintain or increase production and innovate for 
expansion as well as create value-added derivative products and increase foreign exchange countries and especially South Sumatra province.

The area of coffee commodity in South Sumatera is the largest coffee area in Indonesia of $15.190(\mathrm{Ha})$, but with commodity area is not equal to the increase of the population of Indonesia as well as South Sumatera Province so that every year the available land is limited, long ago, as farmers will use their land to grow crops that produce faster to meet their daily needs. Most of the coffee age in the regency or city in South Sumatra is getting older so it needs replanting gradually It is expected that by replanting the coffee market will increase especially the export and not the famous South Sumatra Province as the biggest coffee producer but the famous is Lampung, whereas the coffee in production by Lampung comes from South Sumatra, therefore there needs to be a policy to improve the management system, the promotion of development.

The institutional strengthening aspect is being improved with strong coordination so that it can assist the government in conducting supervision to run coffee development programs. Where institutional strengthening through the empowerment of farmer institutions to form partnerships by building awareness on farmers with a consciousness of community or group that grows on the basis of the need rather than forced from the encouragement of certain projects. Farmer groups that can run their activities independently become the criteria of advanced or business-oriented farmer groups. Government and private assistance in supporting and facilitating farmer partnership activities to increase cooperation partners in the business network. Through this form of partnership is expected to occur transfer of technology, knowledge, and expansion of information for business development.

Counseling on strengthening the effectiveness of institutional coordination of farmers, farmer institutions became an option to facilitate the government to oversee and coordinate. In Law No.16 of 2006, the institutional function is the container of the learning process, cooperation vehicle, the unit of facilities and production infrastructure, processing unit and marketing, and supporting service unit. Once the importance of institutional coordination to carry out its functions properly, so it takes effect in carrying out its services to each member. Optimizing the number of labor available and cooperating with merchants who supply seeds of production equipment quickly and cheaply.

Oil palm plantations consist of smallholder plantation, state plantation and private plantation with total area owned by South Sumatera Province of $1,064,373$ (Ha) so that in Sumatera area of South
Sumatera province the largest area of oil palm is third largest after Riau and North Sumatra. This condition has resulted in the fact that South Sumatera Province has wide potential in the development of oil palm commodity. It is also necessary to replant the oil palm plantations since some of the oil palm plantations have been aged 15 years and over, replanting is done gradually (underplating). Besides replanting the land area can be converted to oil palm plantation which is the factor of supply of CPO to the market, because Indonesia is a producer of CPO other than Brazil, Colombia, Cameroon, and others.

During this time the processing of CPO mostly dominated by large investors, because the investment required to build an MCC unit requires a lot of capital. After mobilizing hundreds of billions of rupiah for mega projects of tens of thousands of hectares of oil palm plantations, further integrating CPO processing into it. The result is that CPO processing technology is very capital-intensive, and it is hard to imagine that a palm oil mill can be made as small and as simple as a rice mill. Although the small-scale and even large scale for an oil palm plantation effort institutional role is very important like financial institution (Bank) and nonbank to reach the condition of palm plasma plantation sustainable. From the labor-intensive nature of these plantations, the availability of abundant labor with sufficient and inexpensive skills does not mean they are not obliged to improve science and technology. The era of globalization and the ASEAN Economic Community (MEA) is very important to learn a technology that progresses so rapidly because it will improve the competitiveness of palm oil commodity.

\section{CONCLUSION}

Results from the SWOT analysis of leading commodities rubber, coffee and palm oil in the districts/cities in South Sumatra are in areas of aggressive strategies that mean short-term or quick to make changes to these commodities. Factors that become the main force for the land area with high soil fertility. While the weakness factor is the quality of commodity productivity is still relatively low, skilled labor is low then the factor of the opportunity of the many traders who supply the commodity, the threat factor of rubber commodity inflated rubber price and inadequate infrastructure.

Strategies that are in the short term or rapidly done optimize the available land by replanting the plant back so that market opportunities increase. The scale of production is enhanced to a greater extent by institutional strengthening. Then the amount of manpower available is much improved and applying appropriate technology by training the workforce. 


\section{REFERENCES}

[1] Akhtar, K., \& Pirzada, S. S. (2014). SWOT Analysis of Agriculture Sector of Pakistan. Journal of Economics and Sustainable Development, 5(11), 127-134.

[2] Badan Pusat Statistik Jakarta Pusat. (2017). Statistik Indonesia Tahun 2017. Jakarta Pusat: Badan Pusat Statis tik.

[3] Collett, S. (1999). SWOT Analysis. Computerworld, (29), 58.

[4] Coman, A., \& Ronen, B. (2009). Focused SWOT: Diagnosing critical strengths and weaknesses. International Journal of Production Research, 47(20), 5677-5689.

[5] Dinas Perkebunan Provinsi Sumatera Selatan. (2016). Statistik Perkebunan.

[6] Dumairy. (1997). . Perekonomian Indonesia. Jakarta.: Erlangga.

[7] Ely, Kartikanidyah.(2014). Analisa Location Quatient dalam Penentuan Produk Unggulan pada Beberapa Sektor di Kabupaten Lingga Kepulauan Riau. Jurnal Integritas Riau.

[8] Hadiguna, R. A. (2012). Model Penilaian Risiko Berbasis Kinerja untuk Rantai Pasok Kelapa Sawit Berkelanjutan di Indonesia. Jurnal Teknik Industri, 14(1), 13-24.

[9] Hafif, B., Ernawati, R., \& Pujiarti, Y. (2014). Peluang peningkatan produktivitas kelapa sawit rakyat di Provinsi Lampung. Jurnal Littri, 20(2), 100-108.

[10] Halwani, R. H. (2002). Ekonomi Internasional dan Globalisasi Ekonomi. Jakarta: Ghalia Indonesia.

[11] Harrison, J. P. (2010). Strategic Planning and SWOT analysis. Essentials of Strategic Planning in Healthcare (Vol. 1). Retrieved from

[12] Jurevicius, O. (2013). Apple SWOT analysis 2013 | Strategic Management Insight. Strategic Management Insight, 3(3), 115-130.

[13] Kementerian Pertanian Direktorat Jenderal Perkebunan. (2016). Statistik Perkebunan 2016.

[14] Krugman, P. R., Obstfeld, M., \& Melitz, M. J. (2012). International economics : theory and policy. Policy (Vol. New York,).

[15] Lahiani, A., Nguyen, D. K., \& Vo, T. (2013). Understanding return and volatility spillovers among major agricultural commodities. Journal of Applied
Business Research, 29(6), 1781-1790.

[16] Marx, K. (1895). The Fetichism of Commodities and The Secret thereof. Capitalist Production, 71-83.

[17] Nopirin. (1999). Ekonomi Internasional (Ketiga). Yogyakarta: BPFE UGM.

[18] Nuga, B. O., \& Asimiea, A. O. (2015). SWOT Analysis of the Nigerian Agricultural Sector. IOSR Journal of Agriculture and Veterinary Science Ver. II, 8(4), 2319-2372.

[19] Panca, A., \& Anhar, M. (2013). Strategi Pengembangan Agroindustri Kelapa Sebagai Upaya Percepatan Ekonomi Masyarakat di Kabupaten Ketapang. Industria, 3(1), 13-26.

[20] Rangkuti, F. (2006). Reorientasi konsep perencanaan strategis untuk menghadapi abad 21. In Analisis SWOT Teknik Membedah Kasus Bisnis (p. 200).

[21] Rahardi,F.2004. AgribisnisBuahIndonesia.Jakarta: PenebarSwadaya.

[22] Undang-Undang Republik Indonesia Nomor 39 Tahun 2014 tentang Perkebunan.

[23] Valeriani, D., \& Wardhani, R. S. (2015). Alternative Tourism in the Belitung Island with the Blue Tourism Concepts as the Effort to Achieve the Quality of Life, Quality of Opportunity and Quality of Experience. Mediterranean Journal of Social Sciences, 6(5).

[24] Wahyudy, H. A., \& Asrol, A. (2015). Analisis Strategi pengembangan agribisnis Karet Rakyat Di Kabupaten Singingi, Provinsi Riau. Dinamika Pertanian, $X X X(3)$, 249-260.

[25] Wardhani, R. S., \& Valeriani, D. (2016). Green Tourism Dalam Pengembangan Pariwisata Bangka Belitung. 